\title{
Enforcing Sustainable Forest Management Policies: An Assessment of the Institutional Structures for VPA Implementation in Ghana
}

\author{
Gordon Kofi Sarfo-Adu \\ Corporate Planning Manager \\ Department of Corporate Planning, Monitoring and Evaluation \\ Forestry Commission, Ghana \\ Tel: 233-244-286-127/233-208-420-472 \\ E-mail: gsarfoadu.hq@fcghana.org/gsarfoadu@gmail.com
}

Received: January 5, 2021 Accepted: February 10, 2021 Published: February 25, 2021

doi:10.5296/emsd.v10i2.18346 URL: https://doi.org/10.5296/emsd.v10i2.18346

\begin{abstract}
Public policy formulation in the forestry management space is an essential step in addressing issues of environmental degradation. That notwithstanding, policies will remain mere intents if they are not forged with appropriate structures and institutional underpinnings. This study assesses the institutional and structural mechanisms adopted to foster effective implementation of the Voluntary Partnership Agreement in Ghana. The qualitative case study design was employed to gather data from purposively selected respondents. The study observes that after ratification of the VPA in Ghana, this was forged with subsequent measures to ensure smooth operationalization of same. The structures include a Legality Assurance System (LAS); chain of custody and wood tracking system (GWTS); establishment of a Timber Verification Department to check and verify the legality of all timbers among others. The structures also entail collaborative governance, transparency and accountability measures to ensure operationalization of the VPA requirements. The study observes that where there are multiple, overlapping and independent actors along the value chain, trust and credibility is built such that those in the downstream of the implementation remain very careful and conscientious in their operations and dealings. The study concludes that relevant implementation structures interspersed with actor constellations, and multi-stake holding remain cornerstone of SFM arrangements.
\end{abstract}

Keywords: Sustainable forest management, Policy implementation, Institutions, Ghana 


\section{Introduction}

Forest resources have many uses and different stakeholders attach specific utility to these resources; some stakeholders put a demand on the resources for their socio-economic livelihoods. Consequently, the past abundance of forest products has evolved into present-day limitations, and it is feared that if appropriate interventions are not put in place, present limitations may eventually result in imminent scarcities with associated negative implications.

Deforestation and forest degradation remain the second leading anthropogenic cause of carbon dioxide emissions which continues to increase global warming (Intergovernmental Panel on Climate Change, IPCC, 2007).

The governance approach has implications on how people and groups interact with forests; in that regard sustainable forest governance approaches have been advocated by different stakeholders. According to McDonald and Lane (2004), policy-makers in many countries recognize in their national forest plans as well as in the international forest policy arena the value of sustainable forest management. The connect between governance systems and sustainable forest management was championed by Dietz et al. (2003) to demonstrate an approach in which the policy process gets dominated by networks of different actors powered by co-operation and consensus orientation. A governance system that underscores the relevance of networks rather than the government acting alone helps in sustainable forest management (Drever et al., 2006; Lebel et al, 2006). Sustainable forest management (SFM) connotes a management regime that balances the social, economic and ecological values associated with forest and considers these values for future generations (Hickey, 2008). Adopting SFM practices has implications on the social, economic and ecological pillars of sustainable development (Luckert \& Williamson, 2005; Drever et al., 2006).

The Voluntary Partnership Agreement is a policy intervention by the EU to help address illegal logging and forest loss. The VPA is a bilateral agreement between the European Union (EU) and wood exporting countries. The initiative aims to improve forest governance and ensure that the wood imported into the EU has complied with the legal requirements of the partner country. The VPA is part of the European Union's action plan (Forest Law Enforcement Governance and Trade) to eliminate illegal timber from its market. Many wood exporting countries have ratified this VPA in their quest to meet to foster SFM and to meet the EU requirements. Optimizing the operationalization of this ratification, especially, in developing countries requires an array of a network of actors rather than the government acting alone (Lebel et al., 2006; Boyle et al., 2001). Whilst there is copious research efforts in the SFM literature, for example the role several institutional factors in SFM (Cortner et al., 1996, 1998); precursors of consensus-building on 'sustainability practices' (Jennings \& Zandbergen, 1995); the processes which make SFM become institutionalized by rules and effective deployment (Meyer \& Baltes, 2004); the literature nonetheless has not adequately assessed implementation and institutional structures for enforcing SFM policies and regulations. Meanwhile, Merlo and Paveri (1997) aver that many of the reasons for a specific policy being unsuccessful are connected with not having the necessary instruments for the 
policy to materialize. That regard policy instruments and appropriate implementation structures constitute the heart of sustainable forest management practices. The main objective of this paper is to assess the implementation structures and policy instruments established for enforcing the EU VPA in wood exporting countries using the experience of Ghana, a West African country. Ghana was among the first countries to ratify this non-legally binding EU VPA in 2007 and has since put up various institutional structures to ensure this policy instrument gets enforced.

\section{Theoretical Framework}

\subsection{Theoretical Framework: Policy Arrangement Approach}

In this research, the policy arrangement approach (PAA) was used to frame the study. The concept of policy arrangement suggests temporary stabilization of the content and organization of a particular policy domain (Van Tatenhove et al, 2000) involving structures formed through processes and interactions among policy actors and rules (Arts \& Leroy, 2006). This approach is more appropriate when a research hinges on the dimensions of actors, power, rules and discourse (Arts \& Van Tatenhove, 2004; Arts \& Leroy, 2006). The framework pays peculiar attention to (1) institutional contexts in which policy actors must operate, (2) the substance of policy-making and (3) the power relations between the policy actors involved (Wiering \& Arts, 2006). As this proposed study discusses impact of VPA implementation on governance and institutional structures of Ghana as well as impact on forest practices, the PAA framework is more appropriate to frame the study. this framework has been applied to analyze dynamics of forest policies elsewhere, including the Netherlands (Veenman et al, 2002), Belgium (Van Gossum et al., 2011) and South Korea (Park \& Youn, 2013).

The PAA as theoretical framework rests on two key philosophies; (i) political modernization and (ii) policy arrangements. Political modernization entails the ever-changing interactions between the state, the market and civil society in political domains of society within national borders and beyond which is manifested in through globalization and Europeanization (Arts $\&$ Van Tatenhove, 2006). An implication is that forest decision processes do not rest with governments of one state or the traditional forest sector alone but polycentric in nature (Verbij, 2008).

The policy arrangement is discussed along following four dimensions: (a) actors and their coalitions involved in the policy domain; (2) the division of resources between these actors (b) the rules of the game and (d) discourses (Arts \& Goverde, 2006; Arts et al., 2006).

\section{Methodology}

The case study design within the qualitative research approach of social research was adopted for the study. The purposive sampling technique was used to select relevant informants to participate in the study. With qualitative study, researchers do not place much emphasis on numbers but the quality of information that would be elicited from participants (Sandelowski, 1995). Both primary and secondary sources of data were used to undertake the study. Primary data was elicited from respondents along the value chain of enforcing Ghana's VPA. 


\section{Ml Macrothink}

The purposive sampling technique was used to select fifty-nine (59) key actors from the Forestry Commission which is the lead government institution for VPA implementation in Ghana and expected to contribute about eighty per cent of VPA implementation. A newly created TVD at FC coordinates VPA implementation process. Key administrative and implementing officials of the relevant units/departments at the Forestry Commission; relevant committees/councils and working groups for VPA implementation and a VPA Secretariat as well as participants from the Ministry of lands and natural resources. Key actors from the Resource Management Support Centre (RMSC), the Forest Service Division (FSD) and the Timber Industry Development Division (TIDD) of Ghana's Forestry Commission were selected. Tropenbos International, a non-state organization which has been active in VPA processes was selected.

Secondary data involved data from journal sources, scholarly books, internet sources, published and unpublished materials relevant to the study. Again, documents from Ministry of lands and natural resources, Forestry Commission of Ghana; Ghana-EU team bulletins and other releases were resorted to.

The main instrument for primary data collection was through the use of in-depth interviews and semi-structured questionnaires. In-depth interview involves face-to-face interaction with key respondents. Data was recorded and transcribed which was subsequently organized through thematic analysis.

\section{Data and Discussion}

This section analyzes and discusses data obtained from the field regarding the institutional structures relevant to implementation of VPA. The study observes institutional structures, processes, actors and interactions which are crucial in the enforcement of VPA protocols. For example, there is a clear definition of what constitutes legal timber which will be allowed to be exported unto the EU market; establishment of specialized Units and Departments within the Forestry Commission to perform oversight responsibilities of the VPA. Precisely, the Forestry Commission has established a Timber Verification Department and TVC to check and verify the legality of all timbers. The introduction of a Legality Assurance System (LAS) which defines what a legal timber entails as well as reorienting all relevant players and stakeholders with this latest development and the processes. To facilitate transparency, accountability and triangulation, there are also independent international monitors who are used as referees in the process as well as relevant civil society organizations who act as independent monitors. These processes and structures have been discussed into themes below.

\subsection{Data}

\subsubsection{Definition of Legal Timber}

The introduction of the VPA has seen a Timber Resources Management and Licensing Legislature considered for enactment to conceptualize what constitutes 'legal timber' in the Ghanaian context as well as the processes for maintaining sustainable forest management. With the VPA, the EU does not dictate what exactly a legal timber is but relies on the exporting member country to use its domestic laws to determine and document legal timber. 
A main cardinal principle of the VPA/Legality Assurance System is the definition of legal timber in Ghana. Respondents unanimously explained that the definition is comprehensive enough and also reflects Forestry Commission manuals, Acts and Legislative Instruments on forestry and timber. A Forestry Manager explained:

"The comprehensive definition leaves nothing behind, it has brought about a complete involvement of all stakeholders which enabled other views to be well discussed"

By defining what constitutes legal timber through a broader stakeholder consultation, this sets the basis for all industrial players and the Forestry Commission to play by the game and to go by the right procedures for obtaining legal timber. However, one of the respondents from a private company noted that the definition appears to leave out some operational legal sources of timber out and that, stakeholder involvement has not been very adequate. Be as it may, respondents demonstrated that the Legality Assurance System (LAS) associated with the VPA clearly directs legality from illegality which is crucial in SFM.

\subsubsection{Ghana Wood Tracking System (GWTS)}

A main system and procedure to foster the VPA implementation is the Ghana Wood Tracking System (GWTS) which acts as a chain of custody that identifies all trees and potential timber unto a software to facilitate the monitoring of wood harvesting. This is an electronic system that keeps a database of all trees within a concession in order to check and address illegality. This system has been structured to ensure openness, verification and cross checking of data on trees which by all standards helps foster sustainable management of forests. A forest manager with a private timber company noted:

The system (GWTS) ensures proper record keeping, checks by TVD (Timber Verification Department) auditors which cause people to do the right thing. Most data which had previously not been a requirement is now being submitted to the FC as part of the GWTS

The point above was corroborated by a forest manager who explained that the GWTS has brought about a revolution in the sustainable management of forest as it has allowed for consistency in information flow throughout the chain and anomalies are easily detected. $\mathrm{He}$ put it this way:

The ability of the system to do reconciliation raises infractions which in effect has made everyone cautious in data inputting such that whatever is fed into the system is consistent with the field.

The GWTS software has intrinsic features which reconcile data on the system with the tree situation on the ground such that those forestry officials who do the data capturing as well as timber companies who are to harvest timber are very careful and cautious not to engage in illegality as the probability of detection is very high with the new trend. A senior forest officer with over twenty years of experience explained:

"it brings all transaction data along the supply chain and also collates and reconciles the data and corrects it from discrepancies... has also helped to remove false reports 
on timber production and export and has helped reduce illegality in timber production.

The strength associated with the structural processes of the VPA especially the GWTS was given by a key officer who made this submission:

"this has helped minimize or avoid raising of red flags and corrective action requirements...it has helped collect all transaction data along the supply chain with the use of the hand-held data logging devices and computers.

Reconciling forest conditions and timber status with a software has promoted transparency and good record keeping in the timber industry. All respondents remained positive on the relevance of the GWTS especially in terms of promoting sustainable forest management and revenue mobilization. One respondent noted:

"It has helped to provide authentic reports on revenue collection, means to monitor payments made by contractors, commission and other levies and obligations"

The GWTS has introduced a real time timber tracking which is an electronic system that helps identify and authenticate timber and its status on time. A District Manager explained:

"timber tracking is almost a paperless activity and the tracking of timber is now done in real time and infractions are also detected in real time"

\subsubsection{Verification (Field Audit)}

Enforcement of the VPA has come with it a Verification System which involves an internal field audit to oversee the extent to which there is conformity to the Legality Assurance System (LAS). More importantly, the internal auditors recheck whether the data captured and entered unto the Ghana Wood Tracking System (GWTS) is accurate and adequately reflects the field conditions. The audit process ensures continuous compliance and applies punitive measures to adverse management of forest resources. Due to this mechanism, field officials and those engaged in data capture and entry remain circumspect and meticulous in the execution of their duties. An assistant District Manager explained:

"it has helped correct errors leading to transparency in the timber industry...people have now become cautious of their dealings and as a result limiting forest offences

The verification process and internal auditing system help to check illegalities thereby improving sustainable forest management by using familiar checklist

The relevance of the verification system is to ensure industrial players, both the Forestry Commission field officials and timber companies comply with the checklist for legality assurance. A key officer at the Timber Verification Department intimated:

It helps address infractions raised during harvesting and it enables companies to work in accordance to standards since audit findings comes with a cost to the company affected 


\subsubsection{Independent Monitor}

Beyond the internal mechanisms of the Forestry Commission to help ensure compliance with the legality assurance through internal audit and verification processes, there are other independent monitoring mechanisms to help in triangulating the verification process. This mechanism makes provision for a specialized individual to ensure all tenets in the processes and standards are complied with. An independent monitor who watches and reports on the processes is a way of helping bring some more transparency and assurance of right doings. A Forestry Officer noted:

"There is an external check to license the VPA process and this exists outside the Forestry Commission...The role of this provision is to ensure the integrity of the system is not compromised. The system allows for a third party assessment of the process, it is not a nuisance but a positive move".

This structure and provision is to ensure that the verification process is not left to the FC only as there is a perception of collusion between officials and timber companies. This was explained by a key officer who noted:

"The system enhances the credibility of the process, it helps to reduce the tendency for corruption which is perceived to be with the FC...the independent monitor has his reputation at stake and will therefore try to do things right and also do the right things.

A forest administrator in one of the Districts explained how the relevance of the independent monitor in ensuring transparency which is a cornerstone of sustainable forest management.

"Transparency is one of the core pillars of SFM, so the third party ensures this is done and it helps both FC and the timber industries to sit up and strategize their activities to conform to standards"

He continued that the role of a body outside the Forestry Commission is desirable and an ideal situation which helps in reinforcing transparency, accountability and good perception of sustainable forest management. An administrator in Goaso Forest District explained:

......it had been argued over the years that the TVD should have been independent off the Commission but once it is still under the FC, it is said that their oversight responsibility may be compromised so the third party which is external to the FC is expected to be independent which adds credibility to the whole LAs process.

This adds another layer of credibility in the sense that it independently audits and delivers its report devoid of influence of the Forestry Commission and industry. Due to this arrangement, it will be difficult for any individual within the FC to subject reports or issues to manipulation.

\subsubsection{Transparency and Accountability in Forest Governance}

The VPA processes and structures which are enforced have helped in opening up the forest and timber trade space to ensure that there is transparency and accountability in the process. 
A District officer explained:

"every information or data on harvesting is readily available on the wood tracking system and can be made available to stakeholders".

\subsubsection{Actors, Governance and Monitoring}

To ensure that established regulations are enforced effectively, the new governance regime has in place different stakeholders or actors who are involved in the governance and monitoring of timber activities from source before export. The main actors include independent auditors (external monitors), civil society organizations/ non-governmental organizations as well as the TVD (internal auditors). All respondents answered in the affirmative to suggest that there are structures and processes which enable various actors to operate professionally without any compromises and collusion. A District Manager noted:

"There are several levels of verification to ensure compliance (levels 1, 2 and 3) as well as the external auditor"

Arguing on how the implementing agencies and structures are poised and positioned for effective enforcement of the VPA, a key informant made this submission:

"the TIDD within the FSD and timber industry operators are very much aligned for effective operationalization of VPA. The law enforcement agencies such as GRA, the police service, and judiciary were all well-educated to understand their roles within the VPA process. The local communities and landowners and resource users were equally educated to understand their roles and responsibilities.

\subsubsection{Training and Capacity Building for Forestry Staff}

Before the operationalization of the VPA, relevant enforcement agencies and stakeholders have been taken through series of training sessions and the provision of relevant logistics to facilitate the enforcement process. One of the respondents intimated:

"Training programmes are instituted and organized for staff in data capture.... An installation of infrastructure for GWTS”,

A Forest District Manager explained how the VPA enforcement has come with supply of logistics and enabling equipment to help effective tracking and monitoring of forest conditions and timber trading activities. He explained:

"There is the provision of logistics which include laptops, mobile devices to help in the data capture, processing and tracking... there is also a preparation of forest management plans and establishment of TVD

\subsection{Discussion, Conclusion and Policy Implications}

To McDermott et al. (2010) forests remain important for their ecosystem services such as provision of biodiversity, regulation of the world's climate, their role in the production of a wide range of wood and non-wood products and as such efforts at promoting sustainability of forest resources and sustainable harvesting. Forests are increasingly regarded as having a key 
role in climate change adaptation and mitigation (Keskitalo et al., 2016; Lindahl \& Westholm, 2012; Nilsson, 2015). The role of legislation and policies remain fundamental in the sustainable governance of natural resources (FAO, 2010; Coleman, 2009).

The VPA began with a quest for a legal framework which defines what constitutes a legal timber source (Legality Assurance System) as well as the role of relevant actors and stakeholders. The findings correspond to an argument by Wiering and Arts (2006) that SFM regulations indicate the extent to which changes in forest management discourse are reflected in changes in regulation or the materialization of policy content or requirements into formal rules. After a policy and legality assurance, the VPA in its operationalization has established some remarkable structural and institutional processes to help in a comprehensive realization of its main objective of enhancing sustainable forest practices.

A Tracking System (WTS) has been introduced into the Ghanaian forestry sector (Ghana Wood Tracking System) to operationalize a chain-of-custody system, which tracks the transportation of wood from the forest, along the entire supply chain, up to the point of export. This arrangement is applicable to all kinds of wood including those imported into Ghana. The findings of this study provide empirical support to Owusu (2009) who conceptually wrote on the policy at an earlier phase before its actual implementation. This current study has served to provide empirical evidence on the VPA enforcement in Ghana and the actual state of affairs since its enforcement.

The process has also established a verification and validation system to guarantee that procedures for achieving timber legality and all administrative requirements are adhered to; a licensing system for issuing a FLEGT license to deserving companies upon meeting and complying with the requirements of the legality assurance system. These are practical measures which motivate and compel timber firms to adopt sustainable forest practices in their logging and timber trading activities.

The role of the independent monitor brings to the table some form of credibility which will bring about some form of trust into the whole arrangement which is explained by Edelenbos and Klijn (2007) to mean a more or less stable perception of actors about the intentions of other actors - which makes them refrain from opportunistic behavior. The role of independent monitors, verification officers, multiple actors and the tendency for the GWTS to access reality in real time all serve as a check to increase trust in the VPA arrangement and enforcement process. Individuals, either as forestry officials or private timber operators at any point in time will be conscientious and relatively honest in their dealings because the value chain has lots of checks and independent verification mechanisms.

Trust is important for SFM because collective action or cross-boundary management is only possible if trust in the reliability of each member's acting in a co-operative way can be guaranteed (Knill, 2000). Important sources of trust are frequent interactions and previous trustworthy relationships (Dasgupta, 2000; Hardy et al., 1998), the expected shared gains of cooperation (Hardin, 2003; Kramer et al., 1996) and respecting others' knowledge and using it in an appropriate way (Charnley et al., 2007). The findings of this current study provide empirical support to an observation by Dean and Pacheco (2017) who use behavioral 
simulation for to assess the role of collaboration and trust in devising workable solutions to environmental issues. The current study observes that where there are multiple, overlapping and independent actors along the value chain, trust and credibility is built such that those in the downstream of the implementation remain very careful and conscientious in their operations and dealings.

The role of stakeholders, governance processes, actor network relations and successful network governance have been regarded as critical success factors in fostering SFM (Meyer $\&$ Baltes, 2004). The current study provides support to the observations by Meyer and Baltes (2004) and Wiering and Arts (2006) who demonstrate that actor constellations, and multi-stake holding remain cornerstone of SFM arrangements.

\section{References}

Ahenkan, A., \& Boon, E. (2010). Assessing the impact of forest policies and strategies on promoting the development of non-timber forest products in Ghana. Journal of Biodiversity, l(2), 85-102. https://doi.org/10.1080/09766901.2010.11884720

Amacher, G. S., Ollikainen, M., \& Koskela, E. (2012). Corruption and forest concessions. Journal of Environmental Economics and Management, 63(1), 92-104.

https://doi.org/10.1016/j.jeem.2011.05.007

Amanor, K. S. (2004). Natural and cultural assets and participatory forest management in West Africa. PERI Working Papers, 63.

Anderson, J., Benjamin, C., Campbell, B., \& Tiveau, D. (2006). Forests, poverty and equity in Africa: New perspectives on policy and practice. International Forestry Review, 8(1), 15-27. https://doi.org/10.1505/ifor.8.1.44

Ansell, C., \& Gash, A. (2008). Collaborative governance in theory and practice. Journal of public administration research and theory, 18(4), 543-571.

https://doi.org/10.1093/jopart/mum032

Arts, B., Leroy, P., \& van Tatenhove, J. (2006). Political modernisation and policy arrangements: a framework for understanding environmental policy change. Public Organizational Review, 6, 93-106. https://doi.org/10.1007/s11115-006-0001-4

Arts , K. A. J., Webster, G., Sharma, N., Melero, C. Y., Mellish, C. S., Lambin, X., \& Van Der Wal, R. (2013). Capturing mink and data: Interacting with a small and dispersed environmental initiative over the introduction of digital innovation. Framework for Responsible Research and Innovation in ICT. University of Aberdeen.

Arts, K., van der Wal, R., \& Adams, W. M. (2015). Digital technology and the conservation of nature. Ambio, 44(4), 661-673. https://doi.org/10.1007/s13280-015-0705-1

Atyi, R. E. A., Assembe-Mvondo, S., Lescuyer, G., \& Cerutti, P. (2013). Impacts of international timber procurement policies on Central Africa's forestry sector: The case of Cameroon. Forest policy and economics, 32, 40-48.

https://doi.org/10.1016/j.forpol.2012.12.006 


\section{Macrothink}

Balsiger, J., \& Van Deveer, S. D. (2012). Navigating regional environmental governance. Global Environmental Politics, 12(3), 1-17. https://doi.org/10.1162/GLEP_e_00120

Bammer, G. (2009). Enhancing research collaborations: Three key management challenges. Research Policy, 37, 875-887. https://doi.org/10.1016/j.respol.2008.03.004

Blaser, J. et al. (2011). Status of Tropical Forest Management 2011. ITTO Technical Series, $38,418$.

Carabelli, E., Bigsby, H., Cullen, R., \& Peri, P. (2007). Measuring sustainable forest management in Tierra del Fuego, Argentina. Journal of Sustainable Forestry, 24(1), 85-108. https://doi.org/10.1300/J091v24n01_05

CARPE. (2001). Central Africa and Forest Governance: Counter-balancing the Powers or Public and Private Interests. Central African Regional Program for the Environment

Cashore, B., \& Stone, M. W. (2012). Can legality verification rescue global forest governance?: Analyzing the potential of public and private policy intersection to ameliorate forest challenges in Southeast Asia. Forest policy and economics, 18, 13-22. https://doi.org/10.1016/j.forpol.2011.12.005

CBD. (2009), Connecting Biodiversity and Climate Change Mitigation and Adaptation. Report of the Second Ad Hoc Technical Expert Group on Biodiversity and Climate Change. Montreal, Technical Series No. 41, 126 pages. [Online] Available: www.cbd.int

Chambers, R., \& Conway, G. (1992). Sustainable rural livelihoods: practical concepts for the 21 st century. Institute of Development Studies (UK).

Charnley, S., Fischer, A. P., \& Jones, E. T. (2007). Integrating traditional and local ecological knowledge into forest biodiversity conservation in the Pacific Northwest. Forest Ecology and Management, 246(1), 14-28. https://doi.org/10.1016/j.foreco.2007.03.047

Colchester, M. (2006). Justice in the Forest; Rural Livelihoods and Forest Law Enforcement. Bogor: CIFOR.

Coleman, E. A. (2009). Institutional factors affecting biophysical outcomes in forest management. Journal of Policy Analysis and Management: The Journal of the Association for Public Policy Analysis and Management, 28(1), 122-146.

https://doi.org/10.1002/pam.20405

Commission on Global Governance. (2015). Our Global Neighbourhood. Oxford: Oxford University Press.

Dasgupta, P. (2000). Economic progress and the idea of social capital. Social capital: A multifaceted perspective, pp. 325-424. https://doi.org/10.1596/0-8213-4562-1

Dean, T. J., \& Pacheco, D. F. (2017). Saving the commons: A behavioral simulation for experiencing the role of collaboration and trust in devising workable solutions to environmental and other social issues. 
Demers, M (2005). Governance: Concepts and Applications. IIAS Working Group, International Institute for Administrative Studies, Brussels.

Dieter, M. (2009). Analysis of trade in illegally harvested timber: Accounting for trade via third party countries. Forest Policy and Economics, 11(8), 600-607.

https://doi.org/10.1016/j.forpol.2009.08.003

Dunn, W. N. (2004). Public policy analysis: an introduction. Upper Saddle River, NJ: Pearson Prentice Hall.

Dye, T.R. (2008). Understanding Public Policy (12th ed.). Upper Saddle River, NJ: Prentice Hall.

Edelenbos, J., \& Klijn, E. H. (2007). Trust in complex decision-making networks: A theoretical and empirical exploration. Administration \& Society, 39(1), 25-50. https://doi.org/10.1177/0095399706294460

EFI. (2009). What Is a Voluntary Partnership Agreement?. [Online] Available:

http://www.euflegt.efi.int/documents/10180/23013/EFI+Policy+Brief+3++What+is+a+Volun tay+Partnersh p+Agreement/076495d8-741e-49da-aeaf-b67e2d3d2239

European Forest Institute. (2018). What is a Voluntary Partnership Agreement? - the European Union Approach. [Online] Available: https://www.efi.int/

Faggin, J. M., \& Offermans, A. (2016). Sustainable Forest Management as a potential integrative approach in international public policy. Sustainable Development Research at ICIS, 189.

Failing, L., \& Gregory, R., (2003). Ten common mistakes in designing biodiversity indicators for forest policy. Journal of Environmental Management, 68, 121-132.

https://doi.org/10.1016/S0301-4797(03)00014-8

FAO. (2010). Biodiversity for Food and Agriculture Contributing to food security and sustainability in a changing world. [Online] Available:

http://www.fao.org/fileadmin/templates/biodiversity_paia/PAR-FAO book_lr.pdf

FAO. (2015). Global Forest Resources Assessment 2015. [Online] Available:

http://www.fao.org/3/a-i4808e.pdf

Ferrer, E. M., \& Nozawa, C. M. C. (1997). Community-based coastal resources management in the Philippines: key concepts, methods and lessons learned.

Gibson, C. C. (2005). Local enforcement and better forests. World Development, 33(2), 273-284. https://doi.org/10.1016/j.worlddev.2004.07.013

Górriz-Mifsud, E., Donazar, L. O., Eseverri, E. M., \& Govigli, V. M. (2017). The challenges of coordinating forest owners for joint management. Forest policy and economics.

Graham, J., \& Plumptre, T. (2003). Governance principles for protected areas in the $21^{\text {st }}$ century. Institute on Governance, Ottawa, Canada 


\section{Macrothink}

Environmental Management and Sustainable Development

ISSN 2164-7682 2021, Vol. 10, No. 2

Grainger, A. (2012). Forest sustainability indicator systems as procedural policy tools in global environmental governance. Global Environmental Change, 22(1), 147-160. https://doi.org/10.1016/j.gloenvcha.2011.09.001

Gunningham, N. (2009). Environment law, regulation and governance: Shifting architectures. Journal of Environmental Law, 21(2), 179-212. https://doi.org/10.1093/jel/eqp011

Hansen, C. P., Rutt, R., \& Acheampong, E. (2018). 'Experimental' or business as usual? Implementing the European Union Forest Law Enforcement, Governance and Trade (FLEGT) Voluntary Partnership Agreement in Ghana. Forest Policy and Economics, 96, 75-82. https://doi.org/10.1016/j.forpol.2018.08.012

Hardin, R. (2003). Gaming trust. Trust and reciprocity: Interdisciplinary lessons from experimental research, 80-101.

Hardy, C., Phillips, N., \& Lawrence, T. (1998). Distinguishing trust and power in interorganizational relations: Forms and facades of trust. Trust within and between organizations, 64-87.

Hickey, G. M., \& Nitschke, C. R. (2007). Monitoring sustainable forest management in the Pacific Rim Region. Journal of Sustainable Forestry, 24(2-3), 245-278.

https://doi.org/10.1300/J091v24n02_08

Hirschberger, P. (2008). Illegal Wood for the European Market. Gland: World Wildlife Foundation.

Hodgson, G. M. (2006). What are institutions?. Journal of economic issues, 40(1), 1-25. https://doi.org/10.1080/00213624.2006.11506879

Humphreys, D. (2014). Forest politics: the evolution of international cooperation. Routledge. https://doi.org/10.4324/9781315870120

Imperial, M. T. (2005). Using collaboration as a governance strategy: Lessons from six watershed management programs. Administration \& Society, 37(3), 281-320.

https://doi.org/10.1177/0095399705276111

Innes, J. L. (2016). Criteria and indicators of sustainable forest management. Sustainable Forest Management: From Concept to Practice. pp. 33.

https://doi.org/10.4324/9780203126547

IPCC. (2007). Fourth Assessment Report. International Panel on Climate Change. [Online] Available: https://www.ipcc.ch/assessment-report/ar4/

Keskitalo, E., Bergh, J., Felton, A., Björkman, C., Berlin, M., Axelsson, P., ... Boberg, J. (2016). Adaptation to climate change in Swedish forestry. Forests, 7(2), 28.

https://doi.org/10.3390/f7020028

Kinnaman, M. L., \&Bleich, M. R. (2004). Collaboration: Aligning resources to create and sustain partnerships. Journal of Professional Nursing, 20(5), 310-322.

https://doi.org/10.1016/j.profnurs.2004.07.009 
Kusumanto, T., Yuliani, E.L., Macoun, P., Indriatmoko, Y., \& Adnan, H. (2005). Learning to Adapt: Managing Forests Together in Indonesia. CIFOR, YGB and PSHK-ODA. Bogor, Indonesia.

\section{Copyright Disclaimer}

Copyright for this article is retained by the author(s), with first publication rights granted to the journal.

This is an open-access article distributed under the terms and conditions of the Creative Commons Attribution license (http://creativecommons.org/licenses/by/4.0/). 